\title{
STUDI KASUS: TANDA DAN GEJALA CITOMEGALOVIRUS PADA BALITA
}

\author{
Iroma Maulida ${ }^{1)}$, Ratih Sakti Prastiwi' ${ }^{2)}$, Adevia Maulidya Chikmah ${ }^{3)}$ \\ iroma.maulida@yahoo.co.id \\ ${ }^{1,2,3)}$ Program Studi Diploma III Kebidanan Politeknik Harapan Bersama \\ Jl. Mataram No. 09 Pesurungan Lor Kota Tegal
}

\begin{abstract}
CMV could cause permanent damage to toddler such as deaf, mental disability, microsomia, eating disorder and event death. We couldn't see any sign of CMV when the baby was born, it could increase risk of transmission to family members. The aim of this study was conducted to determine the sympoms and signs of CMV in toddlers from Tegal City. This study used qualitative methods with a case study approach to parents who have toddlerswith CMV. Samples taken using snowball sampling and obtained 3 informants. The data taken through in-depth interviews using interview guidlines and human instrument. Furthermore, the data tested using referral triangulation.The result of this study indicate that symptomps and signs are commonly found such as fever with diarrhea, seizures or upper respiratory tract infection. Another symptomps are delay in motor development like crawling, sitting and walking. Most informant also experience language delays and are only able to arrange 2 word at the age of 1.5 years old. The diagnose of CMV are carried out by most patients through laboratory result based on IgG and IgM examination. Based on the results, it can be conclude that there were needs to detect baby development intensively so it coul be handled as soos as possible.
\end{abstract}

Keywords: early development detection, $C M V$, toddlers

\begin{abstract}
Abstrak
CMV merupakan penyakit yang dapat menimbulkan masalah permanen pada balita seperti berkurangnya pendengaran, kecacatan mental, ukuran kepala lebih kecil, malas makan dan kematian. Balita dengan CMV tidak menunjukkan tanda dan gejala pada saat bayi lahir, hal tersebut meningkatkan resiko terjadinya penularan pada anggota keluarga. Penelitian ini dilakukan bertujuan untuk mengetahui gejala dan tanda penderita, khususnya pada bayi yang terinfeksi CMV congenital di Kota Tegal. Penelitian menggunakan metode penelitian kualitatif dengan pendekatan studi kasus terhadap orang tua yang memiliki balita yangpernah/sedang menderita CMV. Sampel yang diambil menggunakan teknik snowball sampling dan didapatkan informan sebanyak 3 orang. Data diambil melalui wawancara mendalam menggunakan pedoman wawancara dan human instrument. Selanjutnya, data kemudia diuji kebenarannya melalui triangulasi referen. Hasil penelitian ini menunjukkan bahwa tanda dan gejala yang banyak ditemui seperti demam dengan penyerta berupa diare, kejang atau ISPA. Gejala lain yang muncul adalah adanya keterlambatan dalam perkembangan motorik kasar seperti merangkak, duduk sendiri dan berjalan. Sebagian besar penderita juga mengalami keterlambatan bahasa dan baru mampu merangkai 2 kata pada usia di atas 1,5 tahun. Diagnosa CMV dilakukan oleh sebagian besar penderita melalui pemeriksaan IgG dan IgM. Berdasarkan hasil, dapat disimpulkan perlu adanya deteksi tumbuh kembang yang intensif sehingga jika ada keterlambatan dapat ditangani sesegera mungkin.
\end{abstract}

Kata Kunci: deteksi dini perkembangan, $C M V$, balita

\section{Pendahuluan}

Cytomegalovirus (CMV) merupakan salah satu penyakit menular yang tidak menunjukkan adanya tanda dan gejala. CMV umumnya hanya dapat segera dideteksi apabila terdapat bayi lahir dengan cacat kongenital. Berdasarkan data dari CDC, ditemukan sebanyak 80 dari 100 bayi yang terdiagnosa mengalami infeksi CMV. Bayi yang telah terdiagnosa secara kongenital menunjukkan adanya permasalahan 
permanen seperti berkurangnya pendengaran, kecacatan mental, mikrochepalus, malas makan dan juga dapat menyebabkan kematian pada anak. $^{[1]}$

Infeksi pada bayi dapat terjadi karena adanya penularan CMV dari ibu saat hamil. Ibu yang terinfeksi CMV saat hamil $40 \%$ lebih besar beresiko menularkan pada janinnya dibanding dengan ibu yang terinfeksi sebelum hamil. Semakin awal janin terpapar CMV maka akan semakin besar manifestasi yang akan ditimbulkan ${ }^{1}$. Tidak hanya usia kehamilan saja, rute penularan serta daya tahan tubuh ibu hamil juga akan mempengaruhi manifestasi infeksi pada janin. Hal tersebut yang menyebabkan tanda dan gejala infeksi CMV berbeda-beda bahkan bayi dapat terlihat normal. ${ }^{[2]}$

Bayi yang telah terinfeksi CMV memiliki resiko yang tinggi untuk mengalami infeksi sequel atau lanjutan. Dimana infeksi lanjutan dapat menyebabkan terjadinya abnormalitas perkembangan pada pendengaran, gangguan psikomotor terkadang juga diiringi dengan gangguan neurologik, mikrochepal, retardasi mental serta gangguan pada gigi. ${ }^{[3,4]}$

Hingga saat ini, di Indonesia khususnya Kota Tegal belum banyak ditemui gambaran tanda dan gejala infeksi CMV pada bayi. Untuk mengetahui status terinfeksi $\mathrm{CMV}$, anak harus dilakukan tes antibodi IgG dan IgM yang hanya dapat dilakukan di pelayanan kesehatan. Sedangkan secara kasat mata, tanda dan gejala tidak dapat dilihat pada bayi baru lahir. Hal tersebut meningkatkan resiko penularan langsung pada anggota keluarga. Penularan CMV dapat ditularkan melalui kontak langsung dari penderita CMV melalui darah, air liur, air seni, mani, air mata serta air susu ibu. ${ }^{[5,6,7]}$ Oleh karena itu, penelitian ini dilakukan dengan tujuan mendapatkan gambaran mengenai tanda dan gejala penderita infeksi CMV khususnya pada bayi dan balita di wilayah Kota Tegal sehingga dapat segera dilakukan penanganan sesegera mungkin pada penderita CMV serta dapat dilakukan upaya-upaya pencegahan penularan lebih lanjut pada anggota keluarga penderita CMV.

\section{Metode Penelitian}

Jenis penelitian ini adalah penelitian kualitatif dengan menggunakan pendekatan studi kasus dimana peneliti mengkaji kasus infeksi CMV pada bayi dan balita. Teknik pengambilan sampel yang digunakan adalah snowballing sample dimana sampel diambil hingga data jenuh dengan kriteria orang tua yang anaknya pernah/sedang terinfeksi CMV dan bersedia untuk diwawancarai. [8,9]

Data diambil dengan melakukan wawancara mendalam kepada informan menggunakan panduan wawancara dan human instrument (peneliti sendiri). Data yang sudah didapatkan kemudian dilakukan triangulasi metode, yaitu data hasil wawancara dicrosscheck dengan data yang didapatkan dari dokumentasi seperti hasil pemeriksaan laboratorium. $[8,9]$

\section{Hasil dan Pembahasan}

Dari hasil penelitian didapatkan karakteristik dari informan utama (usia ibu penderita, jumlah anak) jenis kelamin penderita CMV serta usia saat terdeyeksi menderita CMV adalah berikut ini:

Tabel 1 Karakteristik Informan Utama

\begin{tabular}{cccccc}
\hline No & Usia & Anak & $\begin{array}{c}\text { Penderita } \\
\text { CMV } \\
\text { anak ke- }\end{array}$ & $\begin{array}{c}\text { Usia } \\
\text { Anak } \\
\text { (tahun) }\end{array}$ & $\begin{array}{c}\text { Usia } \\
\text { terdiagnosa } \\
\text { CMV } \\
\text { (bulan) }\end{array}$ \\
\hline R1 & 30 & 2 & 2 & 2 & 9 \\
R2 & 43 & 3 & 3 & 6,5 & 18 \\
R3 & 36 & 2 & 2 & 2 & 8 \\
& & & & & \\
\hline
\end{tabular}

Pada tabel diatas dapat dilihat mayoritas anak informan yang menderita infeksi CMV merupakan anak bungsu (terakhir) dan berjenis kelamin laki-laki. Dari seluruh informan diketahui anak kandung yang lebih tua tidak menderita 
CMV. Setelah terdiagnosa CMV, R1 menghentikan pemberian ASI nya sedangkan dua informan lainnya masih melanjutkan ASI dikarenakan anak menolak dan menunjukkan reaksi saat diberikan susu formula atau susu berbahan soya. ASI diketahui merupakan salah satu perantara penularan dari ibu kepada anaknya karena virus CMV bereplikasi dan berada dalam cairan penderita seperti ludah, air seni, darah dan ASI. ${ }^{[7]}$

Dari table 1 diketahui pula bahwa usia anak diketahui terdeteksi CMV berada pada usia 8-18 bulan tahun dan 2 diantaranya terdiagnosa melalui pemeriksaan IgG dan IgM. Hal tersebut menunjukkan adanya kemungkinan penularan terjadi pada saat dalam kandungan ibu (CMV kongenital). Bayi dengan CMV Kongenital, hasil pemeriksaannya terdeteksi $\mathrm{IgG}$ positif dan mengalami kenaikan titer hingga 89 bulan Selain itu IgM tidak dapat diturunkan oleh ibu kepada bayi serta IgM hanya dapat bertahan selama beberapa bulan setelah infeksi sedangkan IgG dapat diturunkan ibu kepada bayinya secara transplasental. ${ }^{[5]}$

\section{Gejala dan Tanda Bayi yang Terinfeksi CMV Kongenital}

Dari hasil wawancara diketahui mayoritas informan menyebutkan bahwa anaknya setelah lahir mengalami permasalahan seperti asfiksia, ikterik serta adanya penurunan haemoglobin. Sehingga bayi perlu diberi tindakan medis untuk menanganinya. Untuk ikterik, salah satu dari informan menyebutkan bahwa ikterik tidak muncul setelah bayi lahir namun ikterik muncul dikarenakan anak mengkonsumsi obat TB.

“...pas usia seminggu kan sempet kuning, bilirubine sampe 15 (jeda) Hb nya ya rendah sampe 8 " (R1, Juni 2017) "pas lair adeknya gak nangis sama sekali mb, warna ne sampe biru" (R3, Juni 2017) "anak saya pernah kuning tapi bukan pas habis lahir (jeda) dulu sebelume kan tes TB positif, trus dikasih dokternya obat TB eeh trus beberapa lama minum obatnya, adeknya tiba-tiba badannya kuning sетиа" (R3, Juni 2017)

Gejala klinis setiap informan berbedabeda antara satu dengan yang lainnya. Namun terlihat gejala yang dominan yaitu adanya demam dan diare yang tidak kunjung sembuh meskipun telah mendapat pengobatan. Adapun demam yang ditunjukkan terus berulang, terdapat satu informan yang menyebutkan bahwa anak pernah mengalami kejang dikarenakan demam tersebut. Sedangkan untuk diare, diare terjadi cukup lama dan merupakan penyakit penyerta dari demam.

“ anaknya demam terus, diberi obat penurun panas atau antibiotik gak mempan (jeda) malahan pas'v' usia 9 bulan kejang... sebelumnya juga pernah kejang pas usia 4 bulan (jeda) itu ya pas demam. Selain demam, ' $V$ ' selalu diare, jadi kalo pas demam pasti selalu diare" (R1, Juni 2017)

“' Z' biasanya diare, diarenya yang gak sembuh-sembuh malahan dulu sampe dirawat di rumah sakit. Kalo demam gak pernah sampe lebih dari 38 tapi ya itu mesti kalo demam mesti diare (jeda) padahal udah dikasih obat diarenya tapi gak mempan" (R3, Juni 2017)

Namun dalam penelitian ini juga ditemukan anak yang terinfeksi CMV tidak menunjukkan gejala klinis seperti demam, diare maupun ISPA. Informan menyebutkan bahwa anak sama sekali tidak pernah sakit sejak usianya masih bayi, hanya terlihat dari adanya keterlambatan perkembangan saja seperti keterlambatan kemampuan untuk duduk sendiri.

“ anak saya gak pernah sakit sama sekali (jeda) gak pernah demam atau kejang juga, gak nyampe seperti itu cuma anaknnya memang telat belum 
bisa duduk kaya anak umumnya lah" (R2, Juni 2017)

Pernyataan informan R2 juga didukung oleh pernyataan informan lainnya dimana anak mengalami keterlambatan perkembangan dibandingkan anak seumurannya. Mayoritas pada usia 9 bulan anak terlihat belum bisa duduk sendiri, perlu bantuan dari orang tua. Untuk informan yang terdeteksi diatas 12 bulan menunjukkan anak saat berdiri perlu dibantu atau dipegangi agar anak tidak jatuh (ambruk).

“ usia 6 bulan tuh ' $V$ ' belum bisa tengkurap, kalo duduk ya masih harus dibantu orangtuanya" (R2, Juni 2017)

"usia 1.5 tahun ' $D$ " belum bisa jalan sendiri, duduk juga belum bisa (jeda) kalo mau berdiri harus dibantu diberdirikan kalo gak anaknya langsung nglesot (jatuh)" (R2, Juni 2017)

"anak saya terlambat (jeda) kalo anak lain kan usia 4 bulan sudah bisa tengkurep sama mbrangkak (merangkak) anak saya belum bisa" (R3, Juni 2017)

Berdasarkan penjelasan diatas, dapat diketahui gambaran gejala dan tanda CMV pada ketiga informan adalah berikut ini:

Tabel 2 Gambaran Tanda dan Gejala CMV IU Tanda dan Gejala

1. a. Usia 1 minggu anak mengalami ikterik, kadar bilirubin dalam tubuh $15 \mathrm{mg} / \mathrm{dl} \mathrm{Hb} 8$

b. Anak menunjukkan gejala sering sakit panas disertai diare sejak usia 6 bulan. Anak memiliki riwayat kejang 2 kali yaitu saat usia 6 bulan dan 9 bulan.

c. Anak mengalami keterlambatan perkembangan motorik kasar. Anak terlihat baru bisa tengkurap saat usia 6. Anak perlu bantuan orang lain saat akan duduk dan dapat duduk sendiri pada usia 11 bulan (setelah pengobatan CMV)

d. Anak belum bisa berbicara, hanya bisa 2 suku kata (mama /ayah) pada usia 1,5 tahun. Pada usia sekarang ( 2 tahun) anak telah bisa merangkai 2 kata yang sederhana, seperti mama maem

2. a. Anak tidak menunjukkan adanya ikterik ataupun demam . Usia 2 tahun 2 bulan, anak mengaami pembesaran/ massa di testis dan perlu dilakukan operasi.

b. Anak mengalami keterlambatan perkembangan motorik kasar. Usia 1.5 tahun belum bisa jalan, belum dapat duduk sendiri, dan saat diberdirikan anak tidak kuat "ambruk/roboh". Anak dapat berjalan setelah usia 2,5 tahun setelah pengobatan CMV dan fisioterapi.

c. Anak mengalami keterlambatan bicara

3. a. Bayi lahir dengan asfiksia. Saat usia neonatus tidak mengalami ikterik

b. Anak $\mathrm{Z}$ pada usia 4 bulan mulai sering demam hingga suhu $39^{\circ} \mathrm{C}$ disertai dengan diare hebat. Setelah mendapat mengobatan TB (rimfampicin) anak mulai menunjukkan adanya ikterik

c. Anak mengalami keterlambatan perkembangan motorik kasar. Pada usia 4 bulan anak belum bisa merangkak dan belum bisa duduk sendiri pada usia 1,5 tahun. Sekarang (2 tahun) sudah bisa duduk sendiri, ngesod dan titah setelah pengobatan CMV dan fisioterapi selama 1 tahun.

d. Anak belum bisa bicara, hanya teriak dan menunjuk sesuatu yang diminta pada usia 2 tahun .

\section{Ket : IU : Informan Utama}

Dari uraian dan tabel tersebut di atas maka secara umum dapat ditarik kesimpulan gejala dan tanda yang sama yang dialami ketiga informan adalah berikut ini.

Tabel 3 Tanda dan Gejala CMV yang sama pada informan

\begin{tabular}{ll} 
No & \multicolumn{1}{c}{ Tanda dan Gejala } \\
\hline 1 & Tanda awal yang ditunjukkan \\
& penderita CMV adalah adanya \\
& panas tinggi yang tidak spesifik \\
& menyerupai ISPA disertai diare \\
& atau kejang. Tanda tanda klinis
\end{tabular}




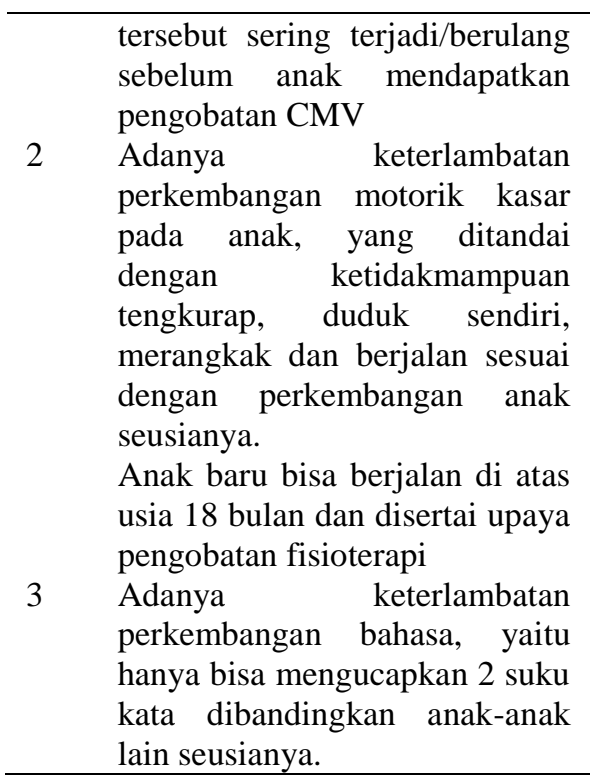

Dari hasil penelitian ditemukan mayoritas anak menunjukkan sering demam tanpa sebab yang jelas disertai diare atau kejang. Beberapa anak juga mengalami tanda hiperbilirubinemia yaitu adanya ikterik pada beberapa anak. Penderita CMV dapat ditemui Cytomegalic Inclusion Disease (CID) yang ditandai dengan hiperbilirubinemia, ptekie, hepatosplenomegali, infeksi saluran nafas (ISPA) dan variasi dari kelainan ekstraneural dan okuloserebral. Beberapa literatur juga menyebutkan ditemukan adanya korioretinitis, mikrosephali, Intra Uterin Growth Retardation (IUGR). ${ }^{[3.10 .11]}$

Infeksi CMV berjalan laten dan sulit diketahui lokasi hidupnya. CMV dapat hidup di dalam bermacam sel seperti sel epitel, endotel, fibroblas, leukosit polimorfnukleus, makrofag yang berasal dari monosit, sel dendritik, limfosit T ( CD4+, CD8+ ), limfosit B, sel progenitor granulosit-monosit dan lainlain. Dengan demikian berarti CMV menyebabkan infeksi sistemik dan menyerang banyak macam organ antara lain kelenjar ludah, tenggorokan, paru, saluran cerna, hati, kantong empedu, limpa, pankreas, ginjal, adrenal, otak atau sistem syaraf pusat. Penjelasan tersebut menunjukkan bahwa CMV dapat hidup dalam limfosit $\mathrm{T}$ yang menyebabkan anak demam tinggi, paru yang menyebabkan anak batuk sehingga mempunyai gejala TB Paru dan hidup pada saluran pencernaan yang menyebabkan anak mempunyai gejala diare. ${ }^{[12]}$

Selain itu virus dapat ditemukan dalam saliva, air mata, darah, urin, semen, sekret vagina, air susu ibu, cairan amnion dan lain-lain cairan tubuh. Ekskresi yang paling umum ialah melalui saliva, dan urin dan berlangsung lama, sehingga bahaya penularan dan penyebaran infeksi mudah terjadi. Ekskresi CMV pada infeksi kongenital sama seperti pada ibu, juga berlangsung lama. ${ }^{[12]}$

Sebagian besar penderita juga mengalami keterlambatan bahasa dan baru mampu merangkai 2 kata pada usia di atas 1,5 tahun. Hal ini sesuai dengan teori bahwa penderita CMV dapat mengalami gangguan perkembangan neurologi. Gangguan perkembangan neurologi merupakan disabilitas primer yang menyerang fungsi sistem saraf dan otak. Bentuk gangguan dapat berupa kesulitan dalam bicara, bahasa, motorik, tingkah laku, belajar, memori, dan berbagai fungsi neurologi lain. Gejala yang ditampilkan pada anak dengan gangguan perkembangan neurologi akan berubah seiring dengan usia pasien dimana beberapa pasien akan mengalami disabilitas yang permanen. [13]

Penderita yang ditemukan dalam keadaan infeksi lanjut dapat ditemukan penyulit sequel yang merupakan manifestasi infeksi CMV. Adapun sequel yang sering ditemui, sebanyak $70 \%$ mengalami keterlambatan perkembangan. ${ }^{[3]}$ Penjelasan literature tersebut juga sesuai dengan hasil dalam penelitian ini dimana semua anak mengalami keterlambatan perkembangan, terutama dalam perkembangan motorik, yaitu terlambat kemampuannya untuk dapat duduk sendiri, maupun kemampuannya dalam berjalan (motorik kasar). Penderita baru bisa berjalan di atas usia 18 bulan. 
Perkembangan motorik, baik motorik halus atau motor kasar juga dipengaruhi oleh sistem saraf pusat yang berada dalam otak manusia. Terganggunya bagian tertentu dalam sistem saraf pusat dapat menimbulkan keterlambatan perkembangan motorik kasar. Hal inilah yang mungkin menyebabkan keterlambatan tengkurap, duduk dan berjalannya penderita CMV. Beberapa orangtua yang memiliki pengetahuan yang baik dalam perkembangan anak mendeteksi lebih cepat keterlambatan anaknya yaitu keterlambatan kemampuan anak untuk tengkurap di usia 4 bulan. Di sinilah pentingnya pengetahuan orangtua tentang perkembangan anak karena semakin cepat keterlambatan perkembangan anak diketahui maka semakin cepat penanganan atas keterlambatan tersebut sehingga kerusakan organ tubuh dapat dihindari dan dampak kerusakan atau kelainan pada anak dapat diminimalkan. [14]

\section{Kesimpulan}

Berdasarkan paparan diatas, dapat diambil kesimpulan bahwa tanda dan gejala yang palingbanyak ditemukan adalah panas tinggi yang tidak spesifik, ada yang disertai dengan diare, kejang dan batuk/pilek. Panas tinggi yang terjadi sering dialami oleh penderita pada usia di bawah 1 tahun. Tanda dan gejala lain yang umum ditemukan adalah adanya keterlambatan pada motorik kasar dan bahasa. Melihat hal tersebut deteksi dini perkembangan anak dapat dijadikan salah satu bentuk deteksi dini CMV.

\section{Daftar Pustaka}

[1]Center for Disease Xontrol and Prevention. CMV fact Sheet for Healthcare Providers; Diagnosem treat, and monitor children with congenital cytomegalovirus (CMV) to hep improve their health outcomes. United State of America: U.S Department of Health and Human Services; 2018.
[2]Lamarre V., Gilbert NL., Rousseau C., Gyorkos TW., Fraser WD. Seroconversion for cytomegalovirus infection in a cohort of pregnant women in Quebec, 2010-2013. Epidemiology and Infection. 2016. 144(8): 1701-1709

[3] Sari WP. Hubungan Abnormalitas Hasil CT-Scan dengan Developmental Delaye dpada Pasien Suspek Infeksi Cytomegalovirus Kongenital. Laporan Hasil Karya Tulis Ilmiah. Semarang: Universitas Diponegoro; 2014.

[4] Bates M and Brantsaeter AB. Human cytomegalovirus (CMV) in Africa: a neglected but important pathogen. Journal of Virus Eradication. 2016. 2: $126-142$

[5] Greanya ED, Partovi N, Yoshida EM, Shapiro RJ, Levy RD, Sherlock $\mathrm{CH}$, et al. The role of the cytomegalovirus antigenemia assay in the detection and prevention of cytomegalovirus syndrome and disease in solid organ transplant recipients: a review of the British Columbia experience. Can J Infect Dis Med Microbiol. 2005. 16(6):335-41

[6] Hadinegoro SR, Chairulfatah A. In: Soedarmo SSP, Garna H, Hadinegoro SR, Satari HI, editors. Buku Ajar Infeksi \& Pediatri Tropis (Edisi ke2). Jakarta: Badan Penerbit IDAI; 2012.

[7] Anggraheny HD, Kurniati ID, Ratnaningrum K.. Buku Ajar Ilmu Obstetrik dan Ginekologi. Semarang: Universitas Muhammadiyah Semarang; 2015.

[8]Sulaeman E. Metode Penelitian Kualitatif dan Campuran dalam Kesehatan Masyarakat. Surakarta: UNS PRESS; 2015.

[9] Idrus M. Metode Penelitian Ilmu Sosial: Pendekatan Kualitatif dan Kuantitatif edisi kedua. Jakarta: Erlangga; 2008.

[10] Rao M and Gopal S. Seroprevalence of Cytomegalovirus in Antenatal Cases with Bad 
Obstetric History at Warangal, Telangana, India. International Journal of Current Microbiology and Applied Sciences. 2015. 4(11): 422-430

[11] Ronchi A, Shimamura M, Malhotra PS, Sánchez P. Encouraging postnatal cytomegalovirus (CMV) screening: the time is NOW for universal screening!. Expert Review of Anti-infective Therapy. 2017. 15(5): 417-419

[12] Mahalakshmi, K. Lily Therese, U. Devipriya, V. Pushpalatha, S. Margarita \& H.N. Madhavan. Infectious Aetiology of Congenital Cataract Based on TORCHES Screening in a Tertiary Eye Hospital in Chennai, Tamil Nadu, India. Journal of Medical Research 131. 2008. page 559-564

[13] Wilujeng Puja Sari (2010). Gambaran CMV Pada Anak. KTI. Semarang: Universitas Diponegoro

[14] Maulida I, Nisa J, Prastiwi R, Hendirana Y. Analisis Model Faktor Perilaku Pemberian Kolostrum di Puskesmas Kesamiran Kabupaten Tegal. Seminar Nasional Kebidanan. 2017. 